\title{
The I-Making, Mine-Making Mind
}

\author{
Ajahn Amaro ${ }^{1}$ \\ Accepted: 4 December 2020 / Published online: 22 January 2021 \\ (C) The Author(s), under exclusive licence to Springer Science+Business Media, LLC part of Springer Nature 2020
}

There is a contrast between the mind caught in the habits of becoming, and the quality of right practice, in which we learn how to work towards realization without creating more confusion.

The term "becoming" features in Buddhist jargon. I remember that when I first showed up in the monastery in Thailand many years ago, this was one of the terms that were being used all the time. "Becoming" and "views and opinions" were words that were repeated over and over again. I remember thinking, "What are they talking about? What is this supposed to mean? Becoming what? What's becoming?" The word did not seem to have any kind of substance. There was no clear sense of what it was referring to, and it was a year or two before I began to get an inkling of exactly what it meant.

The English word "becoming" is a translation of the Pali word bhava, which is sometimes also translated as "being" or "existence." It can refer to all those things, but I prefer the translation "becoming" because it conveys the quality of momentum; there's an implication of movement towards a particular goal or a movement in a direction.

Ajahn Sumedho would avoid talking about any kind of attainments or levels of concentration; he would refrain from talking about reaching jhāna or being concentrated, or attaining levels of enlightenment, because of the danger in that kind of terminology. It very easily ensnares the heart in the habit of becoming, in trying to get something or somewhere and thereby creating more confusion. In the second of the Four Noble Truths, the Buddha defined the cause of dukkha (dissatisfaction) as being tanhha (craving, desire). Mostly, we assume this means desire for sense pleasure, desire for nice, pleasant things, desire for enjoyable experiences (kāma-

Excerpted from The Breakthrough by Ajahn Amaro, Amaravati Publications, 2016.

Ajahn Amaro

ajahn.amaro@gmail.com

1 Great Gaddesden, Amaravati Buddhist Monastery, Hemel Hempstead, Hertfordshire HP1 3BZ, UK $\tanh \bar{a})$, but in the very first discourse that he gave on this theme (the Dhammacakkappavattana Sutta, the Discourse on the Turning of the Wheel of Truth), together with the desire for sense pleasure, the Buddha also lists bhava-tanha $\bar{a}$ and vibhava-tanh $\bar{a}$ - the desire to become, and the desire to get rid of. Käma-tanhā, the desire for sense pleasure, that selfcentered craving, is the one which gets most press, which is talked about most often, and of which we think as being the cause of dukkha. I feel extremely grateful for Ajahn Sumedho's teaching because he would point out that, in terms of meditation, the real obstructions or difficulties do not so much come from the desire for sense pleasure as from the more subtle obstructions, the quiet partners, the outriders; bhava-tanh $\bar{a}$ and vibhava-tanhā. They are the real troublemakers because they can be disguised as good practice, right practice.

The desire for sense pleasure is pretty obvious. Ajahn Chah would tell the story of how, when he was a young monk, he would be sitting in the meditation hall hallucinating about noodles. If you read or listen to his Dhamma talks, you'll see food is mentioned a lot and he was particularly fond of Chinese noodles. He was so fond of them that when he first opened Wat Pah Pong monastery he banned Chinese noodles, because he could see he had a radical attachment to them. There is still something of a tradition at Wat Pah Pong that, one day in the year, they have a "noodle day" - they really let the laypeople lay it on thick, and there are more noodles than you can shake a noodle at.

As a young monk, Ajahn Chah also had an attachment to the fragrant bananas called gluay hom. He said he could taste them in his mouth, he could feel and smell the bananas during the meditation.

These sorts of sense desires are obvious - trying to meditate when not having had supper, fantasizing that we are eating something that we like. That's a pretty obvious kind of craving. But the subtle kinds of craving are the ones that cause more trouble. For example, as I mentioned before, there is the desire to become enlightened, the desire to be concentrated, the desire to attain jhāna, the desire to develop insight, the desire to get rid 
of your defilements, the desire to get rid of your chattering mind and stray habits of thinking.

Now, you might ask: "But aren't we supposed to be doing all those things? If you look at the lists of good qualities, we're advised to develop jhāna or develop insight and to be getting rid of our defilements; getting rid of greed, hatred and delusion, isn't that what we're supposed to be doing?" And, when we look at the texts, we can see that certainly the Buddha in his teachings regularly stresses the problematic nature of greed, hatred, and delusion, and the blessings of concentration and insight and wholesome conduct. So it can be confusing. How can it be that wanting to become enlightened, wanting to become concentrated, wanting to attain insight, wanting to get rid of defilements - how can that be a problem? How can it be an obstruction?

Well, this is where bhava-tanhā and vibhava-tanh $\bar{a}$ come in and how they become a cause for more suffering, because when the heart is caught in that becoming, there is always a sense of self-involved.

Although it might look as if we are following the instructions given in the texts, or we are trying to do the right thing by following the guidance of the teacher, if there is that "me" (ahamkara, the "I-making" element) and "mine" (mamamkara, the "mine-making" element), then we are in the grip of those presences, of bhava-tanha and vibhava$\tanh \bar{a}$. It's "me" trying to be concentrated; "me" trying to enter jhāna; "me" trying to develop insight; "me" getting rid of "my" defilements; "me" trying to quieten "my" chattering thoughts, "me" trying to become a stream-enterer. Me, me, me, me, me! And that can be so familiar, so common, so ordinary, and so unremarkable that it can take over all the effort being made. The whole effort and intention can be compromised by that I-making and mine-making habit. We're not aware. We think we are doing all these wholesome things, and carrying out the practice and following the instructions. But unconsciously and unknowingly we are feeding the causes of suffering. We're feeding the sense of self. We're building more of a quality of self-view.

So then, as my German grandfather would say, "Vat to do?" The contrast, or rather the complement, to bhava-tanha and vibhava-tanh $\bar{a}$ is Right Effort. In the scriptures, the Buddha defines Right Effort as having four parts to it. The first part is restraining unwholesome qualities from arising-samvara is restraint. Then comes pahāna, letting go of anything unwholesome that has already arisen. Bhāvana is the cultivation of the wholesome. And the fourth part is anurakkhanaprotecting, maintaining, or cherishing any wholesomeness that has arisen. Samvira, pahāna, bhāvanā, and anurakkhana - to restrain the unwholesome from arising or, if the unwholesome has arisen, to let it go; to consciously develop the wholesome and to maintain the wholesome in being.
You might be thinking "Hang on a minute- - I thought that a moment ago he was talking about how you didn't want to be doing all that stuff because it could be problematic. So what's the difference?" Well, the difference is that when it's Right Effort there's no sense of self-involved. There is energy being applied. There's a directionality. There is a recognition: "This is unwholesome. Don't let it arise." "This is an unwholesome thing that's already here. Okay, let it go." "This is a wholesome thing. Bring it into being." "This is a wholesome quality. Maintain it. Strengthen it. Keep it alive." But that effort, that directionality, is being applied without the involvement of "I," "me," or "mine."

I like to use the example of the left hand and the right hand. On one level, they look exactly like each other, but on another level they are complete opposites. The bhava qualities, both bhava- and vibhava-tanhā, can be compared to one hand, and the quality of Right Effort, Sammā-vāyāma, can be compared to the other. They look very like each other. Indeed, they can look very, very similar, but essentially they are opposites. One is the troublemaker and the other is the cure.

Almost every time I give meditation teachings, I find it's important to clarify this. I cannot emphasize it enough, because otherwise the teaching can be very confusing. Practitioners may think, "What am I supposed to do? I'm being encouraged to apply effort, but how can you apply effort if it's always going to lead to more dissatisfaction, discontent and alienation?" So we must make a very clear distinction as to whether the motivation is Right Effort or bhava-tanhā/vibhava tanhā. When you are making effort, examine the motivation for the action attentively. What is the guiding force behind the efforts being made? Is the effort being guided by mindfulness and wisdom, or is it being guided by self-view? What's the activating, informing principle behind it? Making this subtle distinction in motivation is crucial, because one type of motivation leads to more $d u k k h a$, while the other leads to the ending of dukkha. They go in opposite directions.

In the practice of meditation, learning to recognize when the mind is applying Right Effort and the practice is being guided by wisdom, by mindfulness, there's a particular quality or tone. Effort is being made but it does not have a compulsive or driven quality to it. There's no obsessiveness. When effort is guided by becoming, by bhava, there's always something of a tone of compulsiveness; the "I, me and mine" element is in there. We have to become familiar with what those two different qualities are like. It's almost like learning to smell the difference between two different kinds of incense, or hearing two different musical notes or discriminating two colors from each other. Growing familiar with the spiritual texture: what does becoming feel like? And what does the ending of becoming feel like? What does the heart free from becoming feel like? 


\section{Addiction to Becoming and the Call of Compassion}

One of our chants recounts the time shortly after the Buddha's enlightenment, when he was invited to teach. Right after his enlightenment, when he became fully awakened, totally enlightened, utterly liberated, he looked round the world and thought he would be unable to teach others. He saw that the world is "addicted to becoming, relishes becoming, it knows only becoming: but what it relishes brings fear and what it fears is pain" (Ud 3.10).

All beings in the world are completely addicted to and absorbed in becoming. All beings are addicted to existence, addicted to being, being something. The Buddha looked round the world and thought, "This entire planet is filled with addicts and I'm the only one who's off the stuff. How on earth am I going to persuade everyone else to go cold turkey? Is there anybody who's going to want to come off the drug?" He concluded that the answer was "No." The whole world is addicted to becoming. The whole world relishes becoming. It knows only becoming. So he decided that there was no point in even trying to explain or teach because it would only be wearying and troublesome, and that he would not even try. If you were given the job of being an addiction counselor to a city of ten million people, all of whom were addicts, where would you start? What would you do? The Buddha thought the task was impossible, that there was absolutely no way of making a dent in that addiction, which is why he concluded that trying would only be "wearying and troublesome to me." So he inclined towards having a quiet life as a hermit and not even bothering to try to teach anybody.

In Buddhist mythology, the Brahma god Sahampati is the creator of the universe. They are not a Supreme Being as you find in other mythologies, but they have the role of the "creator" deity. This makes them one of the highest of the Brahma gods. It's said that when the Buddha decided not to teach, the Brahma Sahampati picked up that thought as it appeared in the mind of the newly Enlightened One. "Oh no! oh no! The mind of the newly awakened Buddha is inclined towards solitude and inaction. Quick! We need to intervene here at once!" And so, Brahma Sahampati descended from the Brahma world, appeared in front of the Buddha and said: "Please, for the sake of those who have only a little dust in their eyes, please teach the Dhamma, because there are some who will understand."

The Buddha listened to that and, moved by compassion, decided: "Let us have another look." He cast his vision around the world, surveyed the minds of all beings and realized: "Yes indeed - Brahma Sahampati is correct, actually there are a few whose faculties are ripe." He used the following image as a simile: "Just as in a pond of red or blue or white lotuses there are some lotuses that are born under the water and never rise up to the surface, there are some lotuses that rise to the surface, and there are some that stand up above the surface and blossom in the sunshine, so too there are some beings with a lot of dust in their eyes, some beings with a medium amount, and some beings with very little dust in their eyes. Those who only have a little bit of dust in their eyes are the ones who can understand." So he agreed to teach, and that's when he set off to the Deer Park in Varanasi to reconnect with his five companions. He found them and explained the Four Noble Truths and the Middle Way to them (as in the Dhammacakkappavattana Sutta). And that's why we have the Buddha's teaching today.

I feel this story is very significant, because to begin with the Buddha felt that every being was completely addicted to becoming. He saw beings caught in this compulsion of identifying with their bodies, their minds, their feeling of defined existence; and that's such an instinctive and fundamental attachment that it is like being addicted to some powerful drug like heroin, crack cocaine or OxyContin. It is such a potent and pervasive addiction that it would be hard for any beings to break free. But to our great benefit he decided to give it a try, and then spent the next forty-five years carrying through that compassionate intention - rousing the effort to teach and explain the insight that he had developed, and helping many beings to kick the habit, break loose, and be free from becoming.

There's also a lovely little exchange between Venerable Sāriputta, who's the Buddha's chief disciple, and Venerable Ānanda who was the Buddha's attendant. They were very good friends, and often had conversations together. Venerable Sāriputta was an accomplished meditator and Ānanda asks him: "Is there a mind state where you can be absorbed in concentration, and the mind is not attending to what is seen or heard or smelled or tasted or touched, and not attending to any mental activity, but yet the mind is aware?" In other words: is there a state where you can be completely awake, yet completely dissociated from the sense world? Venerable Sāriputta answers: "Yes indeed, there is such a state." Ānanda then asks: "So what is the mind aware of if it is in that kind of a state?" Sāriputta answers: "At such a time, in such a state, the mind is aware that Nibbāna is the cessation of becoming" (in Pali, bhavanirodha nibbānam, A 10.7).

The cessation of becoming is Nibbāna.

That's a very lovely phrase. When the heart is free from clinging, attachment, identification, the quality of defined existence; when all that's let go of, this is synonymous with the experience of Nibbāna, of peacefulness, of complete freedom and clarity.

When Ajahn Chah was asked to define Nibbāna, one of his usual descriptions was, "The reality of non-grasping." When the heart is free of grasping, even those subtle kinds, the feeling of being, the feeling of "I and me and mine," free of the quality of bhava, that is the experience of Nibbanna, perfect peacefulness, the true and radical quality of contented ease. 
If you have been meditating for a few years, when sitting with a group, you will have noticed how often the most peaceful and delightful moment of the meditation is when the bell rings. And it's not just because of relief for your knees; so it's good to investigate this delight. Pay attention to the state the mind enters when the bell rings. In addition to relief from pain, there is a moment of release because the mind is not now doing anything. Even though all we were previously doing was meditating, which is built around being peaceful and is a wholesome activity, there was still the quality of "doingness," the presence of "me" doing a "thing." That's the quality of bhava, a quality of grasping and of identification. Ding! Suddenly the mind completely lets go. There's nothing more to do. It can stop.

When we see and reflect on that, we realize: "Hang on a minute! Peace is supposed to be what meditation is for. So how come I keep experiencing it when the meditation stops? Something is going amiss here. Something's out of kilter if I'm only getting peace when the meditation is over, right? It should be the other way round! The peace should be while the meditation is happening. That's when we should be experiencing great peace and clarity, not when the meditation is stopping!"

What so easily happens is that the activity of meditation is co-opted, taken over by the habits of becoming, because of "me" meditating. We think: "I am doing my practice; I am meditating." When we work on clarity, insight or concentration, there is a subtle sense of, "I am working on clarity, I'm developing insight, I'm trying to concentrate." And even when the mind is clear and bright, and there are indeed insight and concentration, there is a degree to which there is a "me" who is doing the meditation. There's a "me" who is the experiencer. There is a "me" who is the agent and a "thing" that is being done. There is tension. There is dukkha. There is a quality of stress in the heart.

You may have had the experience, possibly when you first began meditating and were concentrating on the breath, of finding that breathing was a real chore, really hard work. I remember having this feeling - breathing began to feel like such a lot of work. I remember thinking, "Do I really do this all day long? Have I been doing this my whole life? This is really exhausting!" It was quite comforting to read that Ajahn Chah had exactly the same experience. Then he said to himself, "Hang on a minute - I used to be out working with the water buffaloes, ploughing the fields, and I could breathe all day long and it wasn't any kind of effort. Ploughing the fields was hard work, but breathing was nothing. And now breathing is even worse than ploughing in the rain with the water buffalo. This is really exhausting."

This is because of a slip into "I'm doing the breathing." And because there's that me-ness and trying-ness and doingness, because there is the subtle notion that "I'm doing," and the thing-ness and the me-ness are symptoms of the habits of grasping and becoming - because of that, even the simple act of breathing ends up feeling like a terrible chore. Many times people have said to me, "Ajahn, I am really worried. Am I going to keel over? What am I going to do about oxygen? I'm really worried I'm not breathing enough when I try to practice mindfulness of the breath." It feels so complicated. If one becomes distracted it's all right; the attention is simply brought back to the meditation object and the breath continues quite happily. But if one is actually focusing on the breath and this subtle notion of "I am doing" creeps in, breathing suddenly feels really difficult and you begin to worry. "Am I getting enough oxygen? Am I going to be alright?" It's a quite sincere concern, but its cause is usually just bhava.

This is what can happen, but if we work with it we slowly become more and more familiar with what's happening. Then the sense of self is let go of and the breath is looked upon as just a natural function of the body which is being observed. Slowly but surely there is less interference with the breath. As the practice develops more, the effect of the action of attending lessens and the breath is not affected by the fact that it is being watched.

We guide the practice towards learning to recognize that flavor of becoming - that flavor of attachment to defined being, that way of being I have called "doing-ness" or "me-ness" and "my-ness." The Pali words for this are ahamkara and mamamkara. The word aham means "I am" and kara means "to make" or "to do," so ahamkara means "made of I am." Mamamkara means made of "mine-ness." Mama is the word for "mine" - the primordial owning is the mother by the child: "mama, mama, mama." The child owns the mother. These Pali words are directly descriptive of the heart being caught in those identifications.

We learn to recognize that flavor. We learn to recognize that quality of becoming, and in recognizing it and knowing it, we let go. We learn to relinquish, and in a way we are learning how to practice without the meditation being "a thing that I'm doing." This is tricky territory, because yes, we need to put in a lot of effort into our practice - the Buddha said a number of times, "The Path that I teach is a path of effort." It's a path of doing. It's a path of action. And if you look at the many lists of wholesome qualities which the Buddha gives, such as the Ten Pāramitās, the ten spiritual perfections, viriya, energy or effort, often appears in them. Viriya is one of the Seven Factors of Enlightenment, and one of the Five Spiritual Faculties and Five Spiritual Powers. Right Effort is one of the factors of the Eightfold Path. In all these lists a lot of doing, energy and effort are involved. It's not a path of passivity. But the key is learning how to "do" without a sense of self, how to apply effort without being caught up in attitudes laced with "I" and "me" and "mine."

There was a teacher in Canada called Khema Ananda who used to describe this aspect of the practice as "cultivating diligent effortlessness." That's a useful term to remember: 
diligent effortlessness. Another friend of ours, a Tibetan Lama named Tsoknyi Rinpoche, calls it "undistracted non-meditation." That's another good one to file away: undistracted non-meditation. He would point out that as soon as you call it "meditation," it seems like a program you are following, a thing you are doing. And as soon as the mind has a "thing" it is doing, it easily becomes caught in that compulsiveness, that attitude towards directionality which fixes on getting a result. We need to develop the skill whereby we are wholeheartedly putting forth effort but not trying to get anywhere; whereby we are working really hard but we are completely unattached to the goal towards which we are heading. This is not easy to do, but if we are unable to find that Path, that way of being for ourselves, we will always be letting our efforts be co-opted by attachment to becoming and getting, having and being.

\section{The Ending of Becoming Is Not Stasis}

When we talk about non-attachment or the ending of becoming, it may sound as if we are advocating being passive, or saying we are not supposed to do anything or that we should just be watching without being active. Sometimes, the teaching can come across in that way, particularly in some of the language used in insight meditation instructions: "Just be the watcher, be the observer, be 'the one who knows,' the witness." Those terms are all valid and useful in their own way, but they can suggest a quality of passivity. We can feel, "I should just be watching. I should be aware, which means I shouldn't be doing anything, I shouldn't interfere." We can interpret that quality of just being aware, of being the knowing or just being the witness, as implying that we should not do anything; that any kind of action is somehow intruding upon that true awareness, and that if we have really got it right there will be just awareness and no doing.

I would suggest that this is a misunderstanding of the teaching. There is no kind of wholesome action or intention which is intrinsically disturbing to the quality of awareness. The Middle Way is not to do with being passive or just trying to freeze our involvement in the world. Buddhist practice is not about trying to neutralize our lives. We should not be looking upon our interaction and engagement with the world, the presence of the physical body or our relationship to the planet and other people, as some kind of unfortunate interruption of our pure awareness.

Life, like a dome of many-colored glass,

Stains the white radiance of eternity,

as Shelley put it in "Adonais." Or as in T.S. Eliot's poem "The Love Song of J. Alfred Prufrock":
"Do I dare.

Disturb the universe?"

Rather, awareness is engaged; awareness involves interaction. The development of the Middle Way is a gradual learning that our actions, our intentions and our choices are also part of the way things are. When we are developing a quality of awareness, we are also learning to be aware of our choices, aware of our actions. We should not look upon those choices or actions as somehow distorting awareness, or as a departure from a pure quality of non-attachment. Rather, if those choices, those decisions of action and speech, are guided by mindfulness and wisdom, we will be in accord, we will be in tune with the world around us. We will be in tune with the body, with the planet and the living situation. So that array of actions - what we do, what we say, and the intentions that we have - is not an intrusion upon the way things are. Our actions and intentions are not some kind of departure from harmony, but are brought into accord, into harmony with the way things are.

Pure awareness is not in any way passivity; it is mindful participation. Pure awareness is an attuned participation in the life of our body, our home, our family, our world. We are attuning to the time, the place, the situation. So this quality of letting go is not to do with freezing ourselves or stopping in our tracks, but more about learning how to let our actions, speech and life be in accord with the people we are with, the situation we are in and the needs of the moment. Letting go of becoming is therefore not an exercise in disengaging from society, stopping our thoughts or freezing our emotions. When we are walking on our meditation path, we do not suddenly become frozen in place: that's not the point of the practice. The end of becoming is not stopping your practiceit is letting go of the compulsion, letting go of identification. When it's time to walk, you walk. When it's time to be still, you are still.

In the Buddhist scriptures, there is a useful teaching about a wanderer named Bāhiya who was eventually given by the Buddha the title of "The one who understood the teaching most quickly." Before Bāhiya became a follower of the Buddha, he was under the impression that he was totally enlightened. One night, in his meditation, a devata appeared and said, "Bāhiya, I can tell you're convinced that you're a fully enlightened being - well, I have to let you know that's actually not the case. You are not enlightened and-I am not happy to tell you this, but you are not even on the path to enlightenment."

Bāhiya, to his credit, said, "Oh. That's interesting," and then he asked, "Are there any truly enlightened beings in the world?" The devata replied, "Well, actually, yes - there is a monk, the Samana Gotama, who is truly an arahant, a fully enlightened being, and he is living near the city of Sāvatthi." Right there and then, Bāhiya set off walking with great vigor. 
It was a several hundred-mile journey, but after a number of weeks of travelling, he finally arrived in Sāvatthi. It was early in the morning and the Buddha and a number of the monks were walking through the streets on their morning alms round.

The wanderer Bāhiya approached the Buddha and said, "Venerable Sir, are you the Samana Gotama?"

"Yes, indeed. I am the Samana Gotama."

"I've heard you are an enlightened being and so I would like to ask you to teach me the Dhamma."

"Well, Bāhiya, at this time we're on our alms round. We're in the middle of the city out on the street, so this is not a convenient time for teaching. It would be better if you came along to the Jetavana Monastery later on and I can give you some instruction then."

"Venerable Sir, life is uncertain. It is unknown when either you or I might die, so please teach me the Dhamma here and now."

They went back and forth three times, and after a third time, a Tathägata has to respond, so the Buddha said:

"Listen carefully to what I have to say. In the seen there is only the seen. In the heard there is only the heard. In the sensed there is only the sensed. In the cognized there is only the cognized. When you, Bāhiya, can see that in the seen there is only the seen, and in the heard there is only the heard, and so forth, then you will indeed recognize that there is no thing there; there is no substance in the world of the object. And when you see that there is, indeed, no thing "there," you will also recognize that there is no thing "here"; there is no being or person, no real "I" in the realm of the subject. You will recognize the object is empty, the subject is empty. When you see that there is no thing there and no thing here, you will not be able to find yourself either in the world of this or in the world of that, or any place between the two. This, Bāhiya, is the end of suffering." And Bāhiya instantly became an arahant.

"You will not be able to find a self in the world of this or in the world of that, or in any place between the two..." Bāhiya obviously had some spiritual potential, since he became an arahant right then and there. He then said, "Please, Venerable Sir, may I be your disciple, and will you give me ordination as a monk?" The Buddha asked him, "Have you a robe and a bowl?" Bāhiya was an ascetic who wore clothing made of tree bark, so he did not have a robe or a bowl. The Buddha said, "If you can find a bowl and robe, I will give you the ordination." Bāhiya went off to try and find a robe and a bowl. And as he had correctly feared, his life was indeed short and uncertain; a runaway cow hit him as it was charging through the street, and he died from his wounds. But he died an arahant, so he was right to press the Buddha to give him that teaching.

"In the heard there is only the heard. In the sensed there is only the sensed. In the cognized there is only the cognized...." So as we hear a sound, as we feel a sensation in the body, as we smell, taste or touch something, as we have a thought or a mood - if there is just hearing, just seeing, just smelling, just tasting, just touching, just thinking, just remembering, just feeling - if they are known as just what they are, events in consciousness, then as the Buddha said to Bāhiya, "You will recognize that there is no "thing" there."

When we hear a sound, we might think, "That's the sound of Ajahn Amaro talking," or "That's the sound of a plane going to Luton Airport." And we think that the sound is "out there," the plane is "out there." But if we know it clearly and directly, we recognize that the experience of hearing is not "there"; it's happening in this awareness. The plane is in your mind. The experience of hearing is a pattern of experience in the mind. It's happening here. The mind's representation of that thing is experienced here and now in this field of awareness. And just as you see there is no thing there, that the object is empty, so the feeling of a "me" here who is the experiencer can be seen to be empty too. There's no person who's the experiencer. There's just knowing. There's just the awareness of this moment, the unentangled participating in this pattern of experience.

The Buddha said that when you can see there is no thing there and no thing here, when you can see that the object and subject are both empty, at that point there is just subjectless/ objectless awareness. You will not be able to find a self. You will not be able to find yourself in either the world of objects or the world of the subject, or any place between the two. Just this is the end of suffering.

This teaching is extraordinarily helpful, because we often fill up the world, making a "me" here who is experiencing a world out there. We create a "me" here watching a "mine" out there: "Me watching my mind; me dealing with my thoughts; me and my practice." When that happens, we are not attending in the most skillful and complete way. We are creating a subject here and an object there, both laden with "I" and "mine." So if we bear in mind this simple teaching, it helps us to undermine that I-making and mine-making habit. It dissolves the ahamkara/mamamkara program. It dissolves the causes of self-view. And the more we are able to let there be just seeing, hearing, smelling, tasting, touching; the more we let things take shape, do their thing, without creating a "me" here who's experiencing a world out there, or patterns of thought and feeling and memory inside, the more we recognize our experience as being just patterns of nature coming and going and changing.

Publisher's Note Springer Nature remains neutral with regard to jurisdictional claims in published maps and institutional affiliations. 